\title{
DNER wt Allele
}

National Cancer Institute

\section{Source}

National Cancer Institute. DNER wt Allele. NCI Thesaurus. Code C115971.

Human DNER wild-type allele is located in the vicinity of $2 q 36.3$ and is approximately 357

$\mathrm{kb}$ in length. This allele, which encodes Delta and Notch-like epidermal growth factor-

related receptor protein, is involved in the activation of Notch signaling pathways. 